3 Kantamas Apitanyasai $^{\mathrm{a}}$, Piti Amparyup ${ }^{\mathrm{a}, \mathrm{b}}$, Walaiporn Charoensapsri ${ }^{\mathrm{b}, \mathrm{c}}$, Saengchan Senapin ${ }^{\mathrm{b}, \mathrm{c}}$, 4 E-mail address: anchalee.k@chula.ac.th (A. Tassanakajon).

\section{regulation of caspase-mediated apoptosis \\ Role of Penaeus monodon hemocyte homeostasis associated protein (PmHHAP) in}

(1)

$$
{ }^{a} \text { Center of Excellence for Molecular Biology and Genomics of Shrimp, Department of }
$$
Biochemistry, Faculty of Science, Chulalongkorn University, 254 Phayathai Road, Bangkok

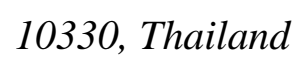

${ }^{b}$ National Center for Genetic Engineering and Biotechnology (BIOTEC), National Science and Technology Development Agency (NSTDA), 113 Paholyothin Road, Klong 1, Klong Luang, Pathumthani 12120, Thailand

\section{${ }^{c}$ Center of Excellence for Shrimp Molecular Biology and Biotechnology (Centex Shrimp),} Mahidol University, Rama VI Road, Bangkok 10400, Thailand

Keywords: Penaeus monodon, Shrimp immunity, Hemocyte homeostasis, Apoptosis, Caspase *Corresponding author. Tel.: +662218 5439; Fax: +662218 5414. Anchalee Tassanakajon ${ }^{\mathrm{a}, *}$

1




\section{Abstract}

The viral responsive protein, PmHHAP, plays an important role in the control of

24 hemocyte homeostasis in shrimps during viral infection. In this study, we further investigate

25 the role of PmHHAP in the regulation of hemocyte apoptosis. RNA interference (RNAi)

26 mediated gene silencing was used to suppress the PmHHAP expression and the change in

27 hemocyte apoptosis was determined in the knockdown shrimp. Within circulating hemocytes,

28 PmHHAP knockdown increased the number of annexin V-positive apoptotic cells and the

29 combined caspase-3/-7 activity and induced the characteristic apoptotic DNA ladder.

30 Furthermore, PmHHAP down-regulation was accompanied by significantly altered

31 expression of apoptosis-related proteins including the effector caspases, PmCaspase and

$32 \quad$ PmCasp. Yeast two-hybrid and co-immunoprecipitation assays showed that PmHHAP binds

33 to the p20 domain of PmCasp. Moreover, the recombinant PmHHAP protein was able to

34 reduce the caspase activity in the actinomycin D-treated hemocyte cells and $\mathrm{rPmCasp}$-treated

35 hemocyte cells. Taken together, our data indicate that PmHHAP regulates hemocyte

36 homeostasis by inhibits apoptotic cell death through caspase activation. 


\section{Introduction}

Hemocyte is considered as an immune-responsive cell that plays the most important role in the immunity of arthropods (Amparyup et al., 2013; Jiravanichpaisal et al., 2006; Johansson et al., 2000; Lavine and Strand, 2002; Tassanakajon et al., 2013). Hemocytes are constantly produced and released from the hematopoietic tissue (Hpt). However, their number in the circulation can transiently dramatically upon injury or in response to microbial infections (Jiravanichpaisal et al., 2001; Johansson et al., 2000; Persson et al., 1987; Smith and Söderhäll, 1983). Homeostasis, achieved by the continuous proliferation and apoptosis, is thus required for the maintenance of hemocyte balance in the circulation. maintained at an appropriate level. It was previously shown that a hemocyte homeostasisassociated protein (PmHHAP) plays a role in hemocyte homeostasis during viral infection in the black tiger shrimp Penaeus monodon (Prapavorarat et al., 2010). Silencing of the PmHHAP transcripts resulted in a greatly decreased level of circulating hemocytes together with hemocyte deformation and lysis (Prapavorarat et al., 2010). In addition, suppression of PmHHAP also led to $100 \%$ mortality of the PmHHAP knockdown shrimp within $30 \mathrm{~h}$ post dsRNA injection, indicating the importance of PmHHAP in shrimp viability (Prapavorarat et al., 2010).

PmHHAP belongs to the zinc finger protein family, which are small regulatory protein domains characterized by a special secondary structure that is stabilized by a zinc ion coordinated with the Cys- and/or His- residues (Klug and Schwabe, 1995). Zinc finger domains can bind to DNA, RNA, proteins and lipids (Hall, 2005) and a role for zinc finger containing proteins in mediating apoptosis has been described previously (Krishna et al., 2003; Verhagen et al., 2001; Vitorino et al., 2014). 
Apoptosis is an evolutionarily conserved cell suicide process that is initiated through the extrinsic caspase-dependent and intrinsic caspase-independent pathways (Galluzzi et al., 2012). The executioner of apoptosis are cysteine-dependent aspartate-directed proteases or caspases. Caspases are synthesized as inactive precursors containing three domains: an amino-terminal prodomain; a large subunit that contains the active-site cysteine (p20); and a carboxy-terminal small subunit (p10) (Riedl and Shi, 2004). In shrimp, several caspase genes have been identified, included PjCaspase from kuruma shrimp P. japonicus (Wang et al., 2008), cap-3 and Lvcaspase2-5 from white shrimp P. vannamei (Rijiravanich et al., 2008; Wang et al., 2013), cap-3 from banana prawn P. merguiensis (Phongdara et al., 2006) and two caspases, PmCasp and PmCaspase, from P. monodon (Leu et al., 2008a; Wongprasert et al., 2007).

Recently, a protein named crustacean hematopoietic factor ( $\mathrm{Pl}-\mathrm{CHF}$ ) has been demonstrated as an essential factor that important in the crossroad between apoptosis and hemocyte differentiation in crayfish Pacifastacus leniusculus. Pl-CHF is a small cysteine-rich protein that most similar to the $\mathrm{N}$-terminal part of the human CRIM1 protein. In vivo and in vitro RNAi experiments revealed severe losses of hemocytes and a higher apoptotic rate in the Hpt cells indicated the roles of $\mathrm{Pl}$-CHF in preventing apoptosis of crayfish hemocytes and Hpt cells (Lin et al., 2011).

In shrimp, our previous study demonstrated that a PmHHAP plays an important role in hemocyte homeostasis (Prapavorarat et al., 2010). However, the mechanism underlying the function of PmHHAP in mediating hemocyte homeostasis in shrimp remains unclear. In the present study, the potential role of $P m$ HHAP in the regulation of hemocyte homeostasis in $P$. monodon shrimps was evaluated using RNAi knockdown and protein-protein interaction assays. Our results suggest that PmHHAP controls hemocyte homeostasis in shrimp by inhibiting the caspase-dependent apoptotic pathway. 
2. Materials and methods

\subsection{Experimental shrimp}

Specific pathogen-free (SPF) shrimp P. monodon were obtained from the Shrimp

Genetic Improvement Center, BIOTEC, Thailand. Shrimp were maintained in tanks with aerated sea water ( $20 \mathrm{ppt}$ ) for 7 days before processing to allow acclimatization.

\subsection{Preparation of double-stranded RNA (dsRNA)}

Double-stranded RNAs (dsRNAs) of PmHHAP and GFP genes were generated using in vitro $\mathrm{T} 7$ RiboMAX ${ }^{\mathrm{TM}}$ Express Large Scale RNA Production System (Promega) as previously described (Prapavorarat et al., 2010) with some minor modifications. Briefly, two PCR reactions were set up using the gene specific primers flanked by a $\mathrm{T} 7$ promoter sequence at the 5' ends (Table 1) to produce the sense and anti-sense strands DNA templates, separately. To generate dsRNA, $1 \mu \mathrm{g}$ of each gel purified PCR products was used as a template for in vitro transcription according to the instruction (Promega). Equal amount of sense and anti-sense single-stranded RNAs were annealed to produce dsRNA and the remaining DNA templates were then digested with RNase-free DNase I (Promega). The quality of dsRNAs was verified by agarose gel electrophoresis with UV visualization following by the ethidium bromide staining and quantified by using UV spectrophotometer.

\subsection{In vivo gene knockdown of PmHHAP and semi-quantitative RT-PCR analysis}

SPF shrimp of $\sim 2 \mathrm{~g}$, fresh weight were used for in vivo RNAi experiments. Briefly, 25 $\mu \mathrm{l}$ of $150 \mathrm{mM} \mathrm{NaCl}$ solution containing $3 \mu \mathrm{g}$ of PmHHAP or GFP dsRNA was injected into each shrimp. At $12 \mathrm{~h}$ post injection (hpi), hemocytes were collected from each shrimp and total RNA was then extracted using the TRI Reagent ${ }^{\circledR}$ (Molecular Research Center) followed 
by DNase I (Promega) treatment. First-stranded cDNA was synthesized with the RevertAid

113 First Strand cDNA Synthesis Kit (Thermo Scientific) according to the manufacturer's

114 instruction. The efficiency of PmHHAP gene transcript silencing was verified by semi-

115 quantitative RT-PCR using the specific primer for PmHHAP gene (Table 1). A fragment of 116 elongation factor $1-\alpha(\mathrm{EF} 1 \alpha)$ was also amplified and used as an internal control. One 117 microlitre of cDNA was used as template for the PCR amplification in a $25 \mu$ reaction 118 volume containing $1 \mathrm{X}$ reaction buffer, $100 \mu \mathrm{M}$ of $\mathrm{dNTP}, 0.2 \mu \mathrm{M}$ of each gene specific 119 primers and 1 unit of RBC Taq DNA polymerase (RBC Bioscience). The thermal cycling was performed at $94{ }^{\circ} \mathrm{C}$ for $1 \mathrm{~min}$, followed by 30 cycles of $94{ }^{\circ} \mathrm{C}$ for $30 \mathrm{~s}, 55^{\circ} \mathrm{C}$ for $30 \mathrm{~s}, 72$ and visualized by UV-transillumination.

\subsection{Apoptosis analysis in hemocyte cells of the PmHHAP silenced shrimp}

DsRNA-mediated RNAi knockdown of PmHHAP gene was performed as described above. Hemolymph was withdrawn from the experimental and control shrimp at 12 hpi with the respective dsRNA and hemocytes were subsequently collected by centrifugation at $800 \times \mathrm{g}$ for 10 min at $4{ }^{\circ} \mathrm{C}$ followed by washing with the phosphate buffer saline (PBS, $\mathrm{pH}$ 7.4). The number of apoptotic hemocytes in the PmHHAP knockdown shrimp and controls were then analyzed using the annexin-V-FLUOS Staining Kit (Roche) according to the manufacturer's protocol. Briefly, the hemocyte number was counted under a light microscope, and then distributed into the wells of a 96-well plate at $10^{4}$ cells per well. Then, the hemocyte cells were incubated with $100 \mu \mathrm{l}$ annexin-V-FLOUS labeling solution for $10-15 \mathrm{~min}$ at room temperature and examined under a fluorescence microscope (Olympus). The positive green 
apoptotic positive cells. The apoptotic hemocyte rate was expressed as the mean \pm S.D. of three replicates.

\subsection{Apoptotic DNA ladder detection in shrimp hemocyte}

To elucidate whether PmHHAP is involved in the control of apoptosis in shrimp $P$. monodon, in vivo RNAi knockdown of PmHHAP gene transcripts was carried out as described above. Control shrimp were injected with GFP dsRNA. The hemocytes were collected from shrimps at 12 hpi and DNA was extracted using the Apoptotic DNA Ladder Detection Kit (Abcam) according to the manufacturer's protocol. Briefly, hemocyte cells were washed with PBS and pellet cells by centrifugation for 5 min at $800 \times \mathrm{g}$. Cells were lysed with TE lysis buffer and then incubated with enzyme A at $37{ }^{\circ} \mathrm{C}$ for $10 \mathrm{~min}$ and with enzyme B at $50{ }^{\circ} \mathrm{C}$ for $30 \mathrm{~min}$. The DNA was precipitated by isopropanol and washed with $70 \%(\mathrm{v} / \mathrm{v})$ ethanol. DNA samples were analyzed on a $1.2 \%(\mathrm{w} / \mathrm{v})$ agarose gel and visualized by under UV light after ethidium bromide staining.

\subsection{Caspase activity assay in shrimp hemocyte}

Activities of key member of the apoptotic pathway (caspase 3 and 7) were determined in hemocyte of PmHHAP knockdown shrimp. At $12 \mathrm{~h}$ post-dsRNA injection, the hemolymph was withdrawn from each shrimp as described above. After centrifugation, the cell pellets were washed with PBS and the total protein concentration of the cell suspension determined using Bradford Reagent (Bio-Rad). An equal concentration of shrimp hemocytes (as protein) from each of three shrimps per treatment was pooled and then analyzed for the caspase- 3 and -7 activity using the Caspase-Glo 3/7 Assay Kit (Promega) according to the manufacturer's instruction. Briefly, $100 \mu \mathrm{l}$ of the pooled hemocyte cell suspension was seeded in the 96-well white plate, and then $100 \mu \mathrm{l}$ of Caspase-Glo reagents was added to each well, gently mixed 
and incubated for $15 \mathrm{~min}$. The luminescence of each sample was then measured in a platereading luminometer (Molecular devices). The data were reported as the mean \pm S.D. of three replicates.

\subsection{Analysis of apoptotic genes expression in PmHHAP knockdown hemocyte using Real-} time RT-PCR

The transcript levels of the apoptotic related-genes were evaluated using quantitative real-time RT-PCR (qRT-PCR). The PmHHAP-silenced and control shrimp were prepared as described above. Shrimp hemocyte (three individuals each) was collected at $12 \mathrm{~h}$ postdsRNA injection. Total RNA was extracted from the hemocyte, and used to synthesize single stranded cDNAs with the RevertAid First Strand cDNA Synthesis Kit (Thermo Scientific). Quantitative real-time RT-PCR was performed using an equal amount of cDNAs in a CFX96 Touch $^{\mathrm{TM}}$ Real-Time PCR Detection system using SsoFast ${ }^{\mathrm{TM}}$ EvaGreen $^{\circledR}$ Supermix (Bio-Rad) with the following conditions: $95{ }^{\circ} \mathrm{C}$ for $8 \mathrm{~min}, 40$ cycles of $95{ }^{\circ} \mathrm{C}$ for $10 \mathrm{~s}, 58{ }^{\circ} \mathrm{C}$ for $15 \mathrm{~s}$ and $72{ }^{\circ} \mathrm{C}$ for $30 \mathrm{~s}$. The specific oligonucleotide primers used for amplification of PmCasp (DQ846887), PmCaspase (EF114674), cathepsin B (EF213113), cathepsin D (EF213114), defender against apoptotic death (DAD1) (EF581986) and survivin (GU903910) are shown in Table 1. The EF1 $\alpha$ was amplified as the internal control and reference standard to verify the quantitative real time PCR reaction. Each real-time PCR reaction was done in triplicate. The results were presented as the relative expression ratios of the target genes expressed in the hemocyte of PmHHAP silenced shrimp versus the GFP control shrimp, with normalization to a reference gene $(\mathrm{EF} 1 \alpha)$ transcript levels in the same cDNA sample.

\subsection{Yeast two-hybrid assay}



domain of PmCasp, p10 domain of PmCasp or PmCasp were carried out basically according to the strategies from the Matchmaker GAL4 Two-Hybrid System (Clontech). The coding sequences of PmHHAP, p20-PmCasp, p10-PmCasp and PmCasp were amplified from total RNA extracted from $P$. monodon hemocytes using SuperScript One-Step RT/Platinum Taq Mix (Invitrogen) with the specific primer pairs PmHHAP-F-NdeI/PmHHAP-R-XhoI, F-p20NdeI/R-p20-BamHI, $\quad$ PmCasp-p10-F-NdeI/R-PmCasp-BamHI and F-PmCasp-NdeI/RPmCasp-BamHI, respectively (Table 1). The amplification reaction and PCR temperature profiles were carried out as described previously (Lertwimol et al., 2014). Except for PmHHAP, which was digested with $N d e \mathrm{I}$ and XhoI, all amplified products were digested with NdeI and BamHI restriction nucleases. The bait plasmid was generated by cloning the purified PmHHAP fragment into the NdeI/SalI site downstream of GAL4 DNA-binding domain (BD) of pGBKT7 (Clontech), while prey plasmids were constructed by cloned the p20-PmCasp, p10-PmCasp and PmCasp fragments into the NdeI/BamHI sites downstream of GAL4 DNA-activation domain vector (AD) of pGADT7 (Clontech). The constructs were subsequently sequenced to confirm gene sequences and correct reading frames. Yeast twohybrid assays were then performed by co-transforming the bait and prey plasmids simultaneously into the yeast cells Saccharomyces cerevisiae strain AH109 using the lithium acetate/dimethyl sulfoxide method (Gietz et al., 1995). Yeast cells were grown on low supplemented with X- $\alpha$-gal (Apollo Scientific). 
211 PmCasp, co-immunoprecipitation (co-IP) was carried out. The recombinant (r) PmHHAP

212 protein and p20 domain (rP20) of PmCasp were produced in E. coli. The NdeI/BamHI 213 digested p20- PmCasp fragment (described above) was inserted in-frame with the $214 N d e \mathrm{I} /$ Bam HI sites of $\mathrm{pET} 15 \mathrm{~b}$ expression vector (Novagen). The recombinant plasmid 215 (pET15b-rP20-PmCasp) was transformed into competent E. coli XL1-Blue and positive 216 recombinant clones were analyzed by DNA sequencing. The selected recombinant plasmid 217 was then transformed into E. coli BL21 (DE3) cells. The His ${ }_{6}$-fusion proteins of PmHHAP 218 (Prapavorarat et al., 2010) and rP20 of PmCasp were expressed by induction with $1 \mathrm{mM}$ 219 isopropyl- $\beta$-D-thiogalactopyranoside (IPTG) and used in the co-IP between rPmHHAP and rP20 of PmCasp. The polyclonal PmHHAP antibody was immobilized and cross-linked with protein A-sepharose CL4B (GE Healthcare) using dimethyl pimelimidate. Fifty microlitres of cross-linked bead was equilibrated with binding buffer (1X PBS, pH 7.4 and $1 \mathrm{M} \mathrm{NaCl}$ ) and then $40 \mu \mathrm{g}$ of $\mathrm{r} P m \mathrm{HHAP}$ and/or $60 \mu \mathrm{g}$ of rP20 of PmCasp were added and incubated at $4{ }^{\circ} \mathrm{C}$ overnight. The proteins were eluted with $100 \mathrm{mM}$ glycine ( $\mathrm{pH} 2.5)$. The immunoprecipitated complexes were then separated by SDS-PAGE (18\% (w/v) acrylamide) and subjected to western blot analysis. The rPmHHAP and rP20 of PmCasp were detected using anti-His tag antibody (1:5000; Millipore) and goat anti-mouse IgG-AP conjugate (1:10,000; Millipore). The positive bands were detected using NBT/BCIP solution.

\subsection{Analysis of PmHHAP-suppressed caspase activation in shrimp hemocyte}

In order to investigate whether PmHHAP can suppress caspase activity in shrimp hemocyte, the caspase activity was detected using Caspase-Glo 3/7 assay (Promega). Hemocytes were collected from five individual shrimp, homogenized in PBS and the total

234 protein concentration of each resultant shrimp hemocyte lysate supernatant (HLS) was 
measured by the Bradford method. Each shrimp HLS was separated into four groups $(150 \mu \mathrm{g}$ of HLS per group made up to a final volume of $100 \mu 1$ with PBS), the first group was incubated with $5 \mu \mathrm{M}$ of $\mathrm{rPmHHAP}$, the second group with $5 \mu \mathrm{M}$ of control protein (bovine serum albumin, BSA) and other groups contain only HLS. After incubation of proteins with actinomycin D (ActD; $50 \mu \mathrm{g} / \mu \mathrm{l})$, Caspase-Glo reagents $(100 \mu \mathrm{l})$ was added and luminescent signals were measured at 15 min using microplate reader (Molecular devices). Moreover, to investigate whether PmHHAP can inhibit the caspase activation directly by PmCasp, the caspase activity detected using Caspase-Glo 3/7 assay (Promega) was performed. After prepared the HLS, shrimp HLS were separated into 4 groups $(150 \mu \mathrm{g}$ of HLS per group made up to a final volume of $100 \mu \mathrm{l}$ with PBS), the first group was incubated with $10 \mu \mathrm{M}$ of $\mathrm{rPmHHAP}$, the second group with $7 \mu \mathrm{M}$ of $\mathrm{rPmCasp}$, the third group with $10 \mu \mathrm{M}$ of $\mathrm{rPmHHAP}$ and $7 \mu \mathrm{M}$ of $\mathrm{rPmCasp}$ and the remaining groups contain HLS with and without BSA. After incubation of proteins for 30 minutes, Caspase-Glo reagents (100 $\mu 1)$ was added and measuring the luminescent signals after 15 min using microplate reader (Molecular devices). The results were expressed as the mean \pm S.D. of three replicates.

\section{Results}

\subsection{Silencing of the PmHHAP gene by dsRA injection}

To understand the functional role of PmHHAP in shrimp hemocyte apoptosis, the gene silencing was performed to suppress the PmHHAP transcript and protein levels in shrimp. After $12 \mathrm{~h}$ of dsRNA injection, total RNA from the hemocytes of knockdown and control shrimp was prepared and subjected to semi-quantitative RT-PCR and Western blot analyses. Successful gene silencing in shrimp was achieved by injection of PmHHAP dsRNA (3 $\mu \mathrm{g} / \mathrm{g}$ shrimp) (Fig. 1A). According to the PmHHAP / EF1 $\alpha$ ratio of DNA band intensity in the knockdown shrimp compared to the control shrimp, approximately $88 \%$ reduction of 
PmHHAP transcript level was observed. Similarly, a marked decrease in the PmHHAP protein level was found in the knockdown shrimp (Fig. 1B).

\subsection{Apoptosis is induced in hemocyte of PmHHAP-knockdown P. monodon}

The level of apoptosis in hemocytes of the PmHHAP-knockdown and control (GFP dsRNA-treated) shrimp was determined by the annexin-V-FLUOS staining assay. Hemocyte cells of the PmHHAP-silencing shrimp (dsPmHHAP) clearly displayed an enhanced FITCconjugated annexin-V signal compare to the control samples (Fig. 2A). The apoptotic rate, as the proportion of annexin-V-positive cells, was increased 2.4-fold in the PmHHAP knockdown shrimp compared to that in the control shrimp injected with GFP dsRNA (Fig. 2B).

\subsection{Apoptotic DNA fragmentation occurred in the PmHHAP-knockdown shrimp} hemocytes

DNA fragmentation is a key characteristic of late apoptosis. To confirm that suppression of PmHHAP induces apoptosis in shrimp hemocyte, the gene silencing experiment was performed as described above. After $12 \mathrm{~h}$ post dsRNA injection, analysis of DNA fragmentation in hemocyte of the knockdown shrimp was evaluated by agarose gel electrophoresis. The characteristic of DNA ladder pattern of apoptosis was detected in the hemocytes of the PmHHAP knockdown shrimp (Fig. 3) but not in the control shrimp, suggesting the role of PmHHAP in controlling apoptosis in hemocytes.

\subsection{Activation of caspase activity in hemocytes from PmHHAP-knockdown P. monodon}

Based on the above results, we hypothesized that the elevated annexin V-positive (apoptotic) cells and DNA fragmentation levels in hemocyte PmHHAP knockdown shrimps 
is associated with the activation of caspase activity levels. To determine whether or not

PmHHAP is involved in the caspase-dependent apoptosis, the activation of caspase- 3 and -7

in hemocyte cells of the knockdown shrimp was analyzed. It was found that the activities of caspase-3 and -7 in hemocyte of the PmHHAP silenced shrimp was increased 3.9-fold at 12 hpi, compared with the control shrimp (Fig. 4). This supports that hemocyte apoptosis was the annexin V-positive apoptotic cells and DNA fragmentation.

292

\subsection{PmHHAP suppression results in the altered expression of effector caspases}

To investigate whether PmHHAP transcript effect to the mRNA expression of apoptotic-related genes in shrimp, dsRNA-mediated gene knockdown of PmHHAP was performed. The different apoptotic related-genes such as two effector caspases PmCasp and PmCaspase, cathepsin B, cathepsin D, defender against apoptotic death (PmDAD1) and survivin were selected for quantitative real-time RT-PCR based evaluation of their relative expression levels. After silencing of PmHHAP, the expression of Pmcasp was slightly decreased while the Pmcaspase was significantly down-regulated (3.4-fold) (Fig. 5A). Moreover, the expression of cathepsin B and cathepsin D showed significantly decreased about 5-fold and 7.5-fold, respectively (Fig. 5A). Transcript levels of anti-apoptotic genes, PmDAD1 and survivin, were significantly lower by about 3.6-fold and 2.9-fold, respectively (Fig. 5A). Because decreased PmHHAP expression levels can lead to an increase caspase activity in shrimp, the effect of suppressing PmHHAP on the expression level of two isoforms of effector caspases in shrimp P. monodon, PmCasp (Wongprasert et al., 2007) and PmCaspase (Leu et al., 2008a) that share 30\% sequence identity, was further evaluated using the quantitative real-time PCR analysis. It was found that the gene silencing of PmHHAP observed at 12, 18, and $24 \mathrm{~h}$ post dsRNA injection (Fig. 5B) was accompanied with a 
reduction of PmCaspase transcript levels at the same time points (Fig. 5B). Interestingly, the mRNA level of PmCasp was significantly increased at $18 \mathrm{~h}$ in hemocyte of the PmHHAP knockdown shrimp (Fig. 5B). These results suggested that suppression of PmHHAP can altered the transcription of effector caspases in the apoptosis pathway.

\subsection{PmHHAP interacts with PmCasp}

Yeast two-hybrid system was performed to detect the interaction of PmHHAP with the effector caspase, PmCasp, or with p20 domain or p10 domain of PmCasp. The results showed that PmHHAP was able to interact with the $p 20$ domain of PmCasp (Fig. 6A), but not with a mature protein or a p10 domain of PmCasp, indicating that PmHHAP is capable of interacting with PmCasp via its p20 subunit. Furthermore, the co-immunoprecipitation assay was applied to verify the existence of the physical association between PmHHAP and p20 subunit of PmCasp. The result confirmed the interaction of PmHHAP with the p20 subunit of PmCasp (Fig. 6B). These results implied that PmHHAP might function with PmCasp to control apoptosis in shrimp.

\subsection{Inhibition of caspase activation in shrimp hemocyte by rPmHHAP}

The ability of PmHHAP to inhibit the apoptosis induced by actinomycin D was evaluated in shrimp HLS. The caspase activation analysis was performed by incubating the rPmHHAP and shrimp hemocyte lysate (HLS) with actinomycin D, followed by measuring the caspase activity. The results revealed that the caspase- 3 and -7 activities were significantly decreased (25\%), compared with the control group (BSA) (Fig. 7A). Moreover, no significant differences in caspase- 3 and -7 activities were noticed among the groups of actinomycin D-treated HLS in the presence or absence of BSA. However, the level of caspase activity in actinomycin D-treated HLS was significantly increased (50\%), compared to non- 
treated HLS. In addition, the inhibition of apoptosis by rPmHHAP though caspase activation was performed by incubating the rPmHHAP and rPmCasp with shrimp hemocyte lysate (HLS), then measuring the caspase activity. It was found that the caspase- 3 and -7 activities in $\mathrm{rPmHHAP}$ and $\mathrm{rPmCasp}$ treated-HLS were significantly decreased (67\%), compared with the rPmCasp-treated HLS (Fig. 7B). No significant differences in caspase-3 and -7 activities was observed among the groups of HLS treated with and without rPmHHAP and with BSA. This result suggested that PmHHAP likely inhibits shrimp hemocyte apoptosis via inhibition of PmCasp activity.

\section{Discussion}

Apoptosis, comprising caspase-dependent and caspase-independent pathways, plays a critical role in biological processes including development, maintaining cells population homeostasis and host defense to pathogenic infection (Bortner et al., 1995; Fuchs and Steller, 2011; Henson and Hume, 2006). Normally, apoptosis is influenced by intracellular signals that directly act on targets within the cells and extracellular signals which required the binding of ligand to the receptor to activate apoptosis (Elmore, 2007). This pathway is initiated by the activation of caspases and results in morphological and biochemical changes and finally demolishes the cell by phagocytosis (Martinvalet et al., 2005). To date, the molecular mechanisms of apoptosis in animals have been well studied (Galluzzi et al., 2012; Kumar, 2007; Riedl and Shi, 2004). In host defense mechanism, apoptosis plays a key role in antiviral in animals by limiting viral multiplication through the destruction of virally infected cells. In many cases, the progeny of virus was decreased in the apoptotic cells and virus multiplication can be interfering by host cells apoptosis (Vandergaast et al., 2011; Koyama et al., 2000). Nevertheless, some viruses have the ability to prevent host cell apoptosis by activation of viral and/or host cell anti-apoptotic proteins and so prolong the viability of the 
host cells sufficiently in order to enhance viral replication, assembly and release (Everett and McFadden, 1999; Koyama et al., 2000, 2003). occur such as chromatin condensation, a degradation of chromosomal DNA into DNA fragments (DNA ladder), formation of apoptotic bodies, nuclear pore disruption and the appearance of phosphatidylserine on the cell surface (Martinvalet et al., 2005; Koyama et al., 2000) as well as the activation of caspases, the key regulators of apoptosis (Saraste et al., 2000). Thus, several methods are used to characterize apoptosis cells including detection of DNA fragmentation, assay of caspase activity and detection of the membrane alteration (Bossy-Wetzel and Green, 2000; Wyllie, 1980).

It has previously been shown that PmHHAP, which is up-regulated after WSSV infection, plays an important role in shrimp hemocyte homeostasis during viral infection (Prapavorarat et al., 2010). Based on the function of PmHHAP in hemocyte homeostasis, we speculate that PmHHAP may be involved in the regulation of hemocyte apoptosis. In the present study, the putative role of PmHHAP as an anti-apoptosis protein was elucidated by RNAi-mediated gene silencing. Suppression of PmHHAP mRNA in shrimp hemocyte caused the translocation of phosphatidylserine to the outer layer of the membrane, as shown by the increased proportion of annexin-V positive cells. Moreover, the apoptotic DNA fragmentation and the increasing caspase 3/7 activity in PmHHAP knockdown hemocyte suggested that PmHHAP likely acts as an anti-apoptotic protein.

Homology analysis of the deduced amino acid sequence revealed that PmHHAP displayed 50 and $65 \%$ amino acid similarity to zinc finger $\mathrm{CCHC}$ domain-containing protein 24 (Zcchc24) of human and insect, respectively (Fig. S1). The Zcchc24 protein is composed of two major domains of different zinc fingers including $\mathrm{zf}-\mathrm{CCHC}$ and $\mathrm{zf}-3 \mathrm{CxxC}$ 
superfamilies, but little is known about the function of this novel protein (Vitorino et al., 2014). Zinc finger proteins (ZFPs) are one of the largest protein superfamilies in animals and are involved in diverse functions, such as DNA/RNA-binding proteins or factors and proteinprotein interactions (Laity et al., 2001). Recently, the expression pattern of a Zcchc24 protein during early development of frogs and chickens was analyzed, where it was suggested that it might be involved in the chicken heart formation (Bento et al., 2011) and in the regulation of apoptosis in heart, somite and branchial arch formation of frogs (Vitorino et al., 2014). However, the expression and biological function of Zcchc24 protein homologues in insect are not known. In shrimp, analysis of PmHHAP protein sequence by SMART program indicated that PmHHAP contains a zinc finger domain of $\mathrm{zf}-3 \mathrm{CxxC}$ superfamily that is similar to the C-terminal zinc finger domain (zf-3CxxC) of Zcchc24 proteins. Generally, the zf-3CxxC domains are identified in several chromatin-associated proteins and are reported to be involved in DNA/ chromatin modifications (Birke et al., 2002; Blackledge et al., 2010). Whether shrimp PmHHAP indeed acts as a chromatin-associated protein was not addressed in this study, but the high sequence similarity of PmHHAP and Zcchc24 proteins in the zinc finger domain support the hypothesis that PmHHAP is involved in the regulation of apoptosis.

There are several genes involve in apoptosis pathway. Cathepsin B, a cysteine 402 proteinase has been reported to be involved in apoptosis (Chweieralski et al., 2006; Liu et al., 2006). In shrimp, cathepsin B was reported to response to Vibrio harveyi infection in P.monodon (Pongsomboon et al., 2008). Cathepsin D, an aspartic proteinase has been reported to induces apoptosis in mammalian cell by working together with caspase and p53 (Chwieralski et al., 2006). In contrast, the role of cathepsin in crustacean apoptosis is still unknown. The defender against apoptotic death (DAD1) is a negative regulator of apoptosis that has been reported to respond to YHV infection in P.monodon (Molthathong et al., 2008). 
Survivin is an inhibitor of apoptosis that not only prevents apoptosis but also plays a role in mitotic regulation (Leu et al., 2008b; Chen et al., 2012). In crustaceans, to date, a number of apoptotic-associated proteins have been characterized including caspases (Lertwimol et al., 2014; Leu et al., 2008a, 2010, 2013; Phongdara et al., 2006; Rijiravanich et al., 2008; Wang et al., 2008, 2013; Wongprasert et al., 2007), inhibitor of apoptosis proteins (IAP) (Leu et al., 2008b, 2012), the mitochondrial related voltage-dependent anion channel (VDAC) (Wang et al., 2010), fortilin (TCTP) (Bangrak et al., 2004), and gC1qR (Watthanasurorot et al., 2010, 2013). In white shrimp Litopenaeus vannamei, silencing of LvIAP1 caused $100 \%$ shrimp PmHHAP (Prapavorarat et al., 2010).

Recently, a crustacean hematopoietic factor (CHF) was functionally characterized in the crayfish Pacifastacus leniusculus. CHF is crucial for the survival of hemocyte and hematopoietic tissue cells by preventing their apoptosis and plays an important role in hemocyte homeostasis and in astakine-induced hematopoiesis of crayfish (Lin et al., 2011). Although $P l \mathrm{CHF}$ and $P m \mathrm{HHAP}$ proteins have similar functions in hemocyte homeostasis via inhibition of apoptosis, their respective nucleotide/amino acid sequences are totally different. Caspases are the major mediators of apoptosis (Thornberry, 1998). Caspases are classified into two different subgroups, initiator and effector caspases (Saivesen, 1999). In shrimp P. monodon, two effector caspase genes (PmCaspase and PmCasp) have been reported (Wongprasert et al., 2007; Leu et al., 2008a). PmCasp is involved in response to WSSV-infection (Wongprasert et al., 2007), but PmCaspase is not (Leu et al., 2008a). According to the present study, PmHHAP appeared to be involved in hemocyte apoptosis, thus, PmHHAP might alter the expression of several apoptotic-related genes and we focus on these two caspases in P. monodon. Suppression of PmHHAP transcripts by RNAi resulted in 
a significant decrease of $P m$ Caspase, whereas $P m$ Casp expression was significantly increased at $18 \mathrm{hpi}$. This result suggested that PmHHAP transcript could altered the mRNA expression of effector caspases but how these two genes/proteins directly function together needs further investigation. In previous study, caspase interaction proteins were characterized especially the inhibitor of apoptosis (IAP) which can bind directly and inhibit caspase activity (Deveraux et al., 1997). In mammalian XIAP can interact with p10 domain of caspase-3 and caspase-9 and inhibit their activity (Verhagen et al., 2001). In Drosophila, DIAP1 interact with caspase Dronc and Drive via BIR domain (Tenev et al., 2005), while DIAP2 can bind with caspase Drice (Leulier et al., 2006). In shrimp P. monodon, the white spot syndrome virus protein WSSV449 or AAP-1 has been shown to bind and cleaved by PmCaspase to inhibit caspase activity (Leu et al., 2008a). Recently, two novel anti-apoptotic proteins of white spot syndrome virus, WSSV134 and WSSV322, were reported to bind to p20 domain of PmCasp (Lertwimol et al., 2014). Surprisingly, yeast two-hybrid and coimmunoprecipitation analyses indicated that PmHHAP protein can interact directly with p20 domain of an effector PmCasp. However, the role of PmCasp, PmHHAP and the two antiapoptotic proteins of WSSV in the regulation of apoptosis during WSSV infection needs to be investigated further. Nevertheless, the data presented here support that PmHHAP plays an important role in controlling hemocyte homeostasis during viral infection by inhibiting apoptosis in shrimp likely via interaction with the effector caspase.

Acknowledgment

This work was supported by research grants from the Thailand Research Fund (TRF 
Japan Science and Technology Agency/Japan International Cooperation Agency, Science and Technology Research Partnership for Sustainable Development (JST/JICA, SATREPS) for equipment support. K.A. is the recipient of a student fellowship from the Royal Golden Jubilee Ph.D. Program, Joint Funding of the Thailand Research Fund and Chulalongkorn University. We acknowledge Chulalongkorn University for the support to the Center of Excellence for Molecular Biology and Genomics of Shrimp.

\section{References}

Amparyup, P., Charoensapsri, W., Tassanakajon, A., 2013. Prophenoloxidase system and its role in shrimp immune responses against major pathogens. Fish Shellfish Immunol. 34, 990-1001.

Bangrak, P., Graidist, P., Chotigeat, W., Phongdara, A., 2004. Molecular cloning and expression of a mammalian homologue of a translationally controlled tumor protein (TCTP) gene from Penaeus monodon shrimp. J. Biotechnol. 108, 219-226.

Bento, M., Correia, E., Tavares, A.T., Becker, J.D., Belo, J.A., 2011. Identification of differentially expressed genes in the heart precursor cells of the chick embryo. Gene Expr. Patterns. 11, 437-447.

Birke, M., Schreiner, S., García-Cuéllar, M.P., Mahr, K., Titgemeyer, F., Slany, R.K., 2002. The MT domain of the proto-oncoprotein MLL binds to CpG-containing DNA and discriminates against methylation. Nucleic Acids Res. 30, 958-965.

Blackledge, N.P., Zhou, J.C., Tolstorukov, M.Y., Farcas, A.M., Park, P.J., Klose, R.J., 2010. CpG islands recruit a histone H3 lysine 36 demethylase. Mol. Cell. 38, 179-190.

Bortner, C.D., Oldenburg, N.B., Cidlowski, J.A., 1995. The role of DNA fragmentation in apoptosis. Trends Cell Biol. 5, 21-26. 
Bossy-Wetzel, E., Green, D.R., 2000. Detection of apoptosis by annexin V labeling. Methods Enzymol. 322, 15-18.

Chen, X.Q., Yang, S., Li, Z.Y., Lu, H.S., Kang, M.Q., Lin, T.Y., 2012. Effects and mechanism of downregulation of survivin expression by RNA interference on proliferation and apoptosis of lung cancer cells. Mol Med Rep. 4, 917-922.

Chwieralski, C.E., Buhling, F., Welte, T., 2006. Cathepsin-regulated apoptosis. Apoptosis.11, $143-149$.

Deveraux, Q.L., Takahashi, R., Salvesen, G.S., Reed, J.C., 1997. X-linked IAP is a direct inhibitor of cell-death proteases. Nature. 388, 300-304.

Elmore, S., 2007. Apoptosis: a review of programmed cell death. Toxicol. Pathol. 35, 495516.

Everett, H., McFadden, G., 1999. Apoptosis: an innate immune response to virus infection. Trends Microbiol. 7, 160-165.

Fuchs, Y., Steller, H., 2011. Programmed cell death in animal development and disease. Cell. $147,742-758$.

Galluzzi, L., Vitale, I., Abrams, J.M., Alnemri, E.S., Baehrecke, E.H., Blagosklonny, M.V., Dawson, T.M., Dawson, V.L., El-Deiry, W.S., Fulda, S., Gottlieb, E., Green, D.R., Hengartner, M.O., Kepp, O., Knight, R.A., Kumar, S., Lipton, S.A., Lu, X., Madeo, F., Malorni, W., Mehlen, P., Nuñez, G., Peter, M.E., Piacentini, M., Rubinsztein, D.C., Shi, Y., Simon, H.U., Vandenabeele, P., White, E., Yuan, J., Zhivotovsky, B., Melino, G., Kroemer, G., 2012. Molecular definitions of cell death subroutines: recommendations of the Nomenclature Committee on Cell Death. Cell Death Differ. $19,107-120$.

Gietz, R.D., Schiestl, R.H., Willems, A.R., Woods, R.A. 1995. Studies on the transformation of intact yeast cells by the LiAc/SS-DNA/PEG procedure. Yeast. 11, 355-360. 
Hall, T.M., 2005. Multiple modes of RNA recognition by zinc finger proteins. Curr. Opin. Struct. Biol. 15, 367-373.

Henson, P.M., Hume, D.A., 2006. Apoptotic cell removal in development and tissue homeostasis. Trends Immunol. 27, 244-250.

Jiravanichpaisal, P., Bangyeekhun, E., Söderhäll, K., Söderhäll, I. 2001. Experimental infection of white spot syndrome virus in freshwater crayfish Pacifastacus leniusculus. Dis. Aquat. Organ. 47, 151-157.

Jiravanichpaisal, P., Lee, B.L., Söderhäll, K., 2006. Cell-mediated immunity in arthropods: hematopoiesis, coagulation, melanization and opsonization. Immunobiology 211, 213236.

Johansson, M.W., Keyser, P., Sritunyalucksana, K., Söderhäll, K., 2000. Crustacean haemocytes and haematopoiesis. Aquaculture. 191, 45-52.

Klug, A., Schwabe, J.W., 1995. Protein motifs 5. Zinc fingers. FASEB J. 9, 597-604.

Koyama, A.H., Fukumori, T., Fujita, M., Irie, H., Adachi, A., 2000. Physiological significance of apoptosis in animal virus infection. Microbes Infect. 2, 1111-1117.

Koyama, A.H., Adachi, A., Irie, H., 2003. Physiological significance of apoptosis during animal virus infection. Int. Rev. Immunol. 22, 341-359.

Krishna, S.S., Majumdar, I., Grishin, N.V., 2003. Structural classification of zinc fingers: survey and summary. Nucleic Acids Res. 31, 532-550.

Kumar, S., 2007. Caspase function in programmed cell death. Cell Death Differ. 14, 32-43.

Laity, J.H., Lee, B.M., Wright, P.E., 2001. Zinc finger proteins: new insights into structural and functional diversity. Curr. Opin. Struct. Biol. 11, 39-46.

Lavine, M.D., Strand, M.R., 2002. Insect hemocytes and their role in immunity. Insect Biochem. Mol. Biol. 32, 1295-1309. 
Lertwimol, T., Sangsuriya, P., Phiwsaiya, K., Senapin, S., Phongdara, A., Boonchird, C., Flegel, T.W., 2014. Two new anti-apoptotic proteins of white spot syndrome virus that bind to an effector caspase (PmCasp) of the giant tiger shrimp Penaeus (Penaeus) monodon. Fish Shellfish Immunol. 38, 1-6.

Leu, J.H., Wang, H.C., Kou, G.H., Lo, C.F., 2008a. Penaeus monodon caspase is targeted by a white spot syndrome virus anti-apoptosis protein. Dev. Comp. Immunol. 32, 476486.

Leu, J.H., Kuo, Y.C., Kou, G.H., Lo, C.F., 2008b. Molecular cloning and characterization of an inhibitor of apoptosis protein (IAP) from the tiger shrimp, Penaeus monodon. Dev. Comp. Immunol. 32, 121-133.

Leu, J.H., Chen, L.L., Lin, Y.R., Kou, G.H., Lo, C.F., 2010. Molecular mechanism of the interactions between white spot syndrome virus anti-apoptosis protein AAP-1 (WSSV449) and shrimp effector caspase. Dev. Comp. Immunol. 34, 1068-1074.

Leu, J.H., Chen, Y.C., Chen, L.L., Chen, K.Y., Huang, H.T., Ho, J.M., Lo, C.F., 2012. Litopenaeus vannamei inhibitor of apoptosis protein 1 (LvIAP1) is essential for shrimp survival. Dev. Comp. Immunol. 38, 78-87.

Leu, J.H., Lin, S.J., Huang, J.Y., Chen, T.C., Lo, C.F., 2013. A model for apoptotic interaction between white spot syndrome virus and shrimp. Fish Shellfish Immunol. 34, 1011-1017.

Leulier, F., Lhocine, N., Lemaitre, B., Meier, P., 2006. The Drosophila inhibitor of apoptosis protein DIAP2 functions in innate immunity and is essential to resist gram-negative bacteria infection. Mol. Cell. Biol. 26, 7821-7831.

Lin, X., Novotny, M., Söderhäll, K., Söderhäll, I., 2010. Ancient cytokines, the role of astakines as hematopoietic growth factors. J. Biol. Chem. 285, 28577-28586. 
Lin, X., Söderhäll, K., Söderhäll, I., 2011. Invertebrate hematopoiesis: an astakine-dependent novel hematopoietic factor. J. Immunol. 186, 2073-2079.

Liu, J., Guo, Q., Chen, B., Yu, Y., Lu, H., Li, Y.Y., 2006. Cathepsin B and its interacting proteins, bikunin and TSRC1, correlate with TNF-induced apoptosis of ovarian cancer cells. OV-90. FEBS Lett. 580, 245-250.

Martinvalet, D., Zhu, P., Lieberman, J., 2005. Granzyme A induces caspase-independent mitochondrial damage, a required first step for apoptosis. Immunity. 22, 355-370.

Molthathong, S., Senapin, S., Klinbunga, S., Puanglarp, N., Rojtinnakorn, J., Flegel, T.W., 2008. Down-regulation of defender against apoptotic death (DAD1) after yellow head virus (YHV) challenge in black tiger shrimp Penaeus monodon. Fish Shellfish Immunol. 24, 173-179.

Persson, M., Cerenius, L., Söderhäll, K., 1987. The influence of haemocyte number on the resistance of the freshwater crayfish, Pacifastacus leniusculus Dana, to the parasitic fungus Aphanomyces astaci. J. Fish Dis. 10, 471-477.

Phongdara, A., Wanna, W., Chotigeat, W., 2006. Molecular cloning and expression of caspase from white shrimp Penaeus merguiensis. Aquaculture. 252, 114-120.

Pongsomboon, S., Wongpanya, R., Tang, S., Chalorsrikul, A., Tassanakajon, A., 2008. Abundantly expressed transcripts in the lymphoid organ of the black tiger shrimp, Penaeus monodon, and their implication in immune function. Fish Shellfish Immunol. $25,485-493$.

Prapavorarat, A., Vatanavicharn, T., Söderhäll, K., Tassanakajon, A., 2010. A novel viral responsive protein is involved in hemocyte homeostasis in the black tiger shrimp, Penaeus monodon. J. Biol. Chem. 285, 21467-21477.

Riedl, S.J., Shi, Y., 2004. Molecular mechanisms of caspase regulation during apoptosis. Nat. Rev. Mol. Cell. Biol. 5, 897-907. 
Rijiravanich, A., Browdy, C.L., Withyachumnarnkul, B., 2008. Knocking down caspase-3 by RNAi reduces mortality in Pacific white shrimp Penaeus (Litopenaeus) vannamei challenged with a low dose of white-spot syndrome virus. Fish Shellfish Immunol. 24, $308-313$.

Salvesen, G.S., Dixit, V.M., 1999. Caspase activation: the induced-proximity model. Proc. Natl. Acad. Sci. U.S.A. 96, 10964-10967.

Saraste, A., Pulkki, K., 2000. Morphologic and biochemical hallmarks of apoptosis. Cardiovasc. 45, 528-537.

Smith, V.J., Söderhäll, K., 1983. $\beta$-1,3 glucan activation of crustacean hemocytes in vitro and in vivo. Biol. Bull. 164, 299-314.

Tanev, T., Zachariou, A., Wilson, R., Ditzel, M., Meier, P., 2005. IAPs are functionally nonequivalent and regulate effector caspases though distinct mechanisms. Nat. Cell Biol. 7 , $70-77$.

Tassanakajon, A., Somboonwiwat, K., Supungul, P., Tang, S., 2013. Discovery of immune molecules and their crucial functions in shrimp immunity. Fish Shellfish Immunol. 34, 954-967.

Thornberry, N.A., 1998. Caspases: key mediators of apoptosis. Chem. Biol. 5, R97-R103.

Vandergaast, R., Kimberly, L.W.S., Rebecca, J.C., Paul, D.F., 2011. Active depletion of host cell inhibitor-of-apoptosis proteins triggers apoptosis upon baculovirus DNA replication. J. Virol. 85, 8348-8358.

Verhagen, A.M., Coulson, E.J., Vaux, D.L., 2001. Inhibitor of apoptosis proteins and their relatives: IAPs and other BIRPs. Genome Biol. 2, reviews3009.1-reviews3009.10.

Vitorino, M., Correia, E., Serralheiro, A.R., De-Jesus, A.C., Inácio, J.M., Belo, J.A., 2014. Expression pattern of zcchc24 during early Xenopus development. Int. J. Dev. Biol. 58, $45-50$. 
Wang, L., Zhi, B., Wu, W., Zhang, X., 2008. Requirement for shrimp caspase in apoptosis against virus infection. Dev. Comp. Immunol. 32, 706-715.

Wang, K.C., Kondo, H., Hirono, I., Aoki, T., 2010. The Marsupenaeus japonicus voltagedependent anion channel (MjVDAC) protein is involved in white spot syndrome virus (WSSV) pathogenesis. Fish Shellfish Immunol. 29, 94-103.

Wang, P.H., Wan, D.H., Chen, Y.G., Weng, S.P., Yu, X.Q., He, J.G., 2013. Characterization of four novel caspases from Litopenaeus vannamei (Lvcaspase2-5) and their role in WSSV infection through dsRNA-mediated gene silencing. PLoS One. 8, e80418.

Wongprasert, K., Sangsuriya, P., Phongdara, A., Senapin, S., 2007. Cloning and characterization of a caspase gene from black tiger shrimp (Penaeus monodon)infected with white spot syndrome virus (WSSV). J. Biotechnol. 131, 9-19.

Watthanasurorot, A., Jiravanichpaisal, P., Söderhäll, I., Söderhäll, K., 2010. A gC1qR prevents white spot syndrome virus replication in the freshwater crayfish Pacifastacus leniusculus. J. Virol. 84, 10844-10851.

Watthanasurorot, A., Jiravanichpaisal, P., Söderhäll, K., Söderhäll, I., 2013. A calreticulin/gC1qR complex prevents cells from dying: a conserved mechanism from arthropods to humans. J. Mol. Cell. Biol. 5, 120-131.

Wyllie, A.H., Kerr, J.F., Currie, A.R., 1980. Cell death: the significant of apoptosis. Int Rev Cytol. 68, 251-306. 
Figure 1. Successful RNAi-mediated gene silencing of PmHHAP transcripts and protein levels in P. monodon hemocytes. (A) Semi-quantitative RT-PCR analysis of the gene silencing efficiency of PmHHAP dsRNA at the transcript level. Shrimp injected with GFP dsRNA served as controls. EF1 $\alpha$ was amplified and used as an internal control. The average relative expressions are representative of three independent repeat \pm 1 S.D. (error bars).

Western blot analysis of the PmHHAP and $\beta$-actin proteins in the PmHHAP silenced hemocytes. $\beta$-actin was used as the loading control. Each lane represents the protein from the pooled sample of three individual shrimp.

637

Figure 2. Detection of apoptosis in hemocyte of PmHHAP-silenced P.monodon by annexin V staining. Hemocytes were collected from the PmHHAP knockdown and control GFP dsRNA injected shrimp at $12 \mathrm{~h}$ after dsRNA injection and stained with annexin-VFLUOS (A). The propidium iodide (PI) was used to counter stain the hemocyte nucleus. The annexin-V positive cells were counted under the microscope and the apoptosis rate of PmHHAP-silenced shrimp and that of the GFP control was reported (B). The proportion of annexin-V positive cells, counted under a flourescent microscope, in PmHHAP-silenced and GFP control shrimps, shown as the mean \pm 1 S.D., and derived from triplicate experiments. Asterisk indicates a statistical significant difference between means $(* * * p<0.001)$.

647 prepared from hemocytes of the PmHHAP-silenced shrimp and the GFP-injected shrimps 
instruction and electrophoresed on $1.2 \%(\mathrm{w} / \mathrm{v})$ agarose gel. The figure shown is

652

653

654

655

656

657

658

659

660

661

662

663

664

665

666

667

668

669

670

671

672

673

674

675 representative of the triplicate experiments. Lane $\mathrm{M}$ is a $1 \mathrm{~kb}$ molecular weight DNA marker.

Figure 4. Caspase 3/7 activity in hemocyte of PmHHAP-silenced $P$. monodon. Hemocytes were collected from PmHHAP and GFP dsRNA-injected shrimps, and the caspase 3/7 activity was measured. The column represents the mean \pm 1 S.D. derived from three separate shrimps. Asterisk indicates a statistical significant difference between means $\left({ }^{*} p<0.05\right)$.

Figure 5. Effect of PmHHAP silencing on expression of apoptotic related genes in shrimp. (A) The effect of PmHHAP knockdown at 12 hpi on the expression level of genes involved in apoptosis (Pmcasp, Pmcaspase, cathepsin B, cathepsin D, DAD1 and survivin) were evaluated by quantitative real-time RT-PCR. (B) The effect of PmHHAP gene knockdown on the transcript expression level of PmHHAP, PmCaspase and PmCasp at each time point (hpi) was evaluated by quantitative real-time RT-PCR. EF1 $\alpha$ was served as the internal reference gene to normalize the amount of cDNA template. The data represent the mean \pm 1 S.D. derived from three independent experiments.

Figure 6. Interaction of $P m$ HHAP with PmCasp protein. (A) The protein-protein interaction between PmHHAP and the mature protein, p20 and p10 domains of PmCasp, as determined by yeast two-hybrid assay. The PmHHAP was in-frame with the BD domain of the pGBKT7 plasmid, whilst the mature protein, p20 and p10 domains of PmCasp were inframe with the AD domain of pGADT7, respectively. Interaction (+) is indicated by blue yeast colonies and no interaction (-) by no growth. BD and AD constructs co-transformed in yeast are indicated. (B) The protein-protein interaction between PmHHAP and the p20 domain of PmCasp revealed by Co-immunoprecipitation assay. The immunoprecipitated 
676 complex between rPmHHAP and p20 domain (rP20) of PmCasp was detected using the 677 polyclonal anti-PmHHAP antibody. The proteins were separated by SDS-PAGE and 678 analyzed by Western blotting with anti-His antibody.

679

680 Figure 7. In vitro inhibition of caspase activation by rPmHHAP. (A) Hemocyte lysate 681 supernatant (HLS) was incubated with rPmHHAP in the presence or absence of actinomycin 682 D. Control groups were HLS only and HLS incubated with BSA. (B) Hemocyte lysate 683 supernatant (HLS) was incubated with rPmHHAP, rPmCasp and co-incubated with both 684 rPmHHAP and rPmCasp, control group was HLS with and without BSA protein control. Total caspase activity was detected using the Caspase-Glo 3/7 assay kit. The results are expressed as the mean \pm S.D. of three replicates. Means with a different lowercase letter are significantly different $(p<0.05)$.

688

689

690

691

692

693

694

695

696

697

698

699 
Nucleotide sequence of the primers used.

\begin{tabular}{|c|c|c|}
\hline Primer & Sequence (5'-3') & $\begin{array}{c}\text { GenBank } \\
\text { accession number }\end{array}$ \\
\hline \multicolumn{3}{|l|}{ Real-time RT-PCR } \\
\hline PmHHAP-F & 5' GCAACAGGAGAACCTGTGGATA 3' & HQ130431 \\
\hline PmHHAP-R & 5' GGTTCCAGAATCGCCTCCTATA 3' & HQ130431 \\
\hline PmCasp-F & 5' TAAACTTCACGGCTGAACGG 3' & DQ846887 \\
\hline PmCasp-R & 5' TCAGCATGGATGGGAATCAC 3' & DQ846887 \\
\hline PmCaspase-F & 5' CGTGGTTCATTCAGTCGCTG 3' & EF114674 \\
\hline PmCaspase-R & 5' AACCTTTCGCATCAGGGTTG 3' & EF114674 \\
\hline Cathepsin B-F & 5' ATGAGTGATCGGCAGTGTATCC 3' & EF213113 \\
\hline Cathepsin B-R & 5' GATGCAGATCACTCTCGTAGTC 3' & EF213113 \\
\hline Cathepsin D-F & 5' GACCAAGTCCTCCACATACAAG 3' & EF213114 \\
\hline Cathepsin D-R & 5' GTGACTCCATCAACAGCAATCC 3' & EF213114 \\
\hline PmDAD1-F & 5' АCTCCTTCCTTCTGGGTTCA 3' & EF581986 \\
\hline PmDAD1-R & 5' AAATCAGCAAAGCCTCGTTC 3' & EF581986 \\
\hline Survivin-F & 5' CCTGACCTCGTCCGTTCGTTTG 3' & GU903910 \\
\hline Survivin-R & 5' GGTTGTCTCACTCTCTGCCTTTG 3' & GU903910 \\
\hline $\mathrm{EF} 1 \alpha-\mathrm{F}$ & 5' GGTGCTGGACAAGCTGAAGGC 3' & \\
\hline $\mathrm{EF} 1 \alpha-\mathrm{R}$ & 5' CGTTCCGGTGATCATGTTCTTGATG 3' & \\
\hline \multicolumn{3}{|l|}{ Gene silencing } \\
\hline PmHHAPi-F & 5' GCAACAGGAGAACCTGTGGATA 3' & HQ130431 \\
\hline PmHHAPi-R & 5' GGCCTTGTGACGTTCTTCCATT 3' & HQ130431 \\
\hline T7PmHHAPi-F & $\begin{array}{l}\text { 5' TAATACGACTCACTATAGGGCAACAGGAG } \\
\text { AACCTGTGGATA 3' }\end{array}$ & HQ130431 \\
\hline T7PmHHAPi-R & $\begin{array}{l}\text { 5' TAATACGACTCACTATAGGGGCCTTGTGAC } \\
\text { GTTCTTCCATT 3, }\end{array}$ & HQ130431 \\
\hline GFP-F & 5' ATGGTGAGCAAGGGCGAGGA 3 & U55761 \\
\hline GFP-R & 5' TTACTTGTACAGCTCGTCCA 3 & U55761 \\
\hline GFPT7-F & $\begin{array}{l}5, \text { TAATACGACTCACTATAGGATGGTGAGCAA } \\
\text { GGGCGAGGA } 3 \text {, }\end{array}$ & U55761 \\
\hline GFPT7-R & $\begin{array}{l}\text { 5' TAATACGACTCACTATAGGTTACTTGTACAG } \\
\text { CTCGTCCA 3' }\end{array}$ & U55761 \\
\hline \multicolumn{3}{|l|}{ Yeast two-hybrid } \\
\hline PmHHAP-F-NdeI & 5' CATATGAGCGCCGAAATGAAAACC 3' & HQ130431 \\
\hline PmHHAP-R-XhoI & 5' CTCGAGGCGTTTATAGGAGGCGATTCT 3' & HQ130431 \\
\hline F- $P m$ Casp-p20-NdeI & 5' GGAATTCCATATGCCGCGGGGCGCTGCTCT 3' & DQ846887 \\
\hline $\begin{array}{l}\text { R- PmCasp-p20- } \\
\text { BamHI }\end{array}$ & 5' CGCGGATCCGTCGGGGCCCCTGCATGCCTG 3' & DQ846887 \\
\hline PmCasp-p10-F-NdeI & 5' GGAATTCCATATGTACCCAGGATTCCCGGC 3' & DQ846887 \\
\hline F-PmCasp-NdeI & 5' GGAATTCCATATGAGCGACGCCGACGACTC 3' & DQ846887 \\
\hline R-PmCasp-BamHI & 5' CGCGGATCCTCAGAAGTAAATTTCACGAAG 3' & DQ846887 \\
\hline
\end{tabular}


Figure 1

Figure 1.

(A)
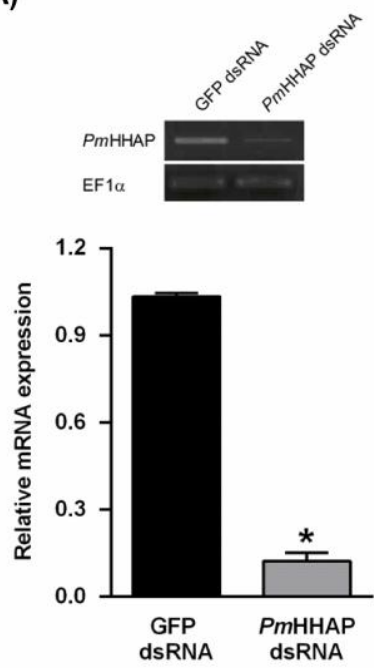

(B)

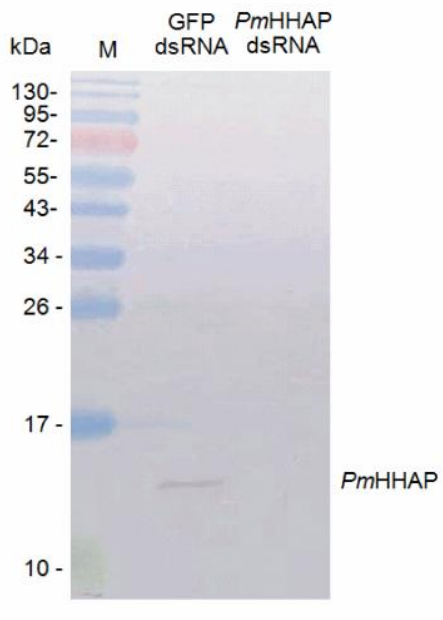

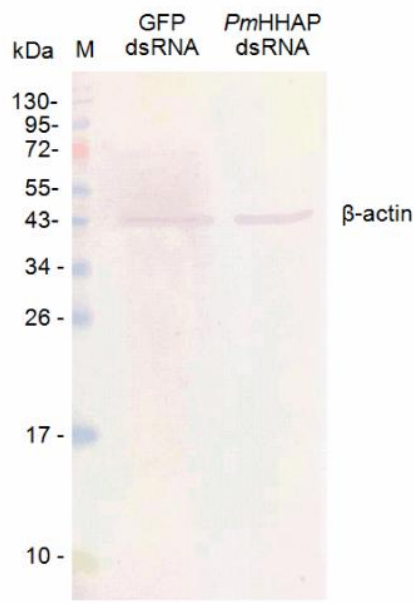


Figure 2

Figure 2.

(A)

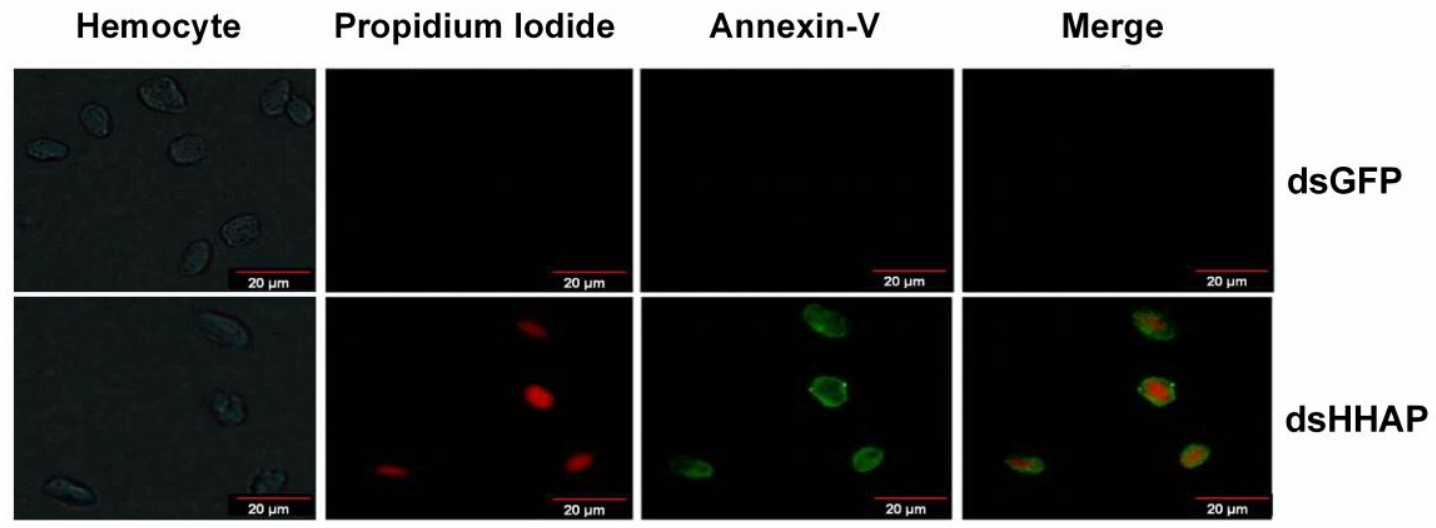

(B)

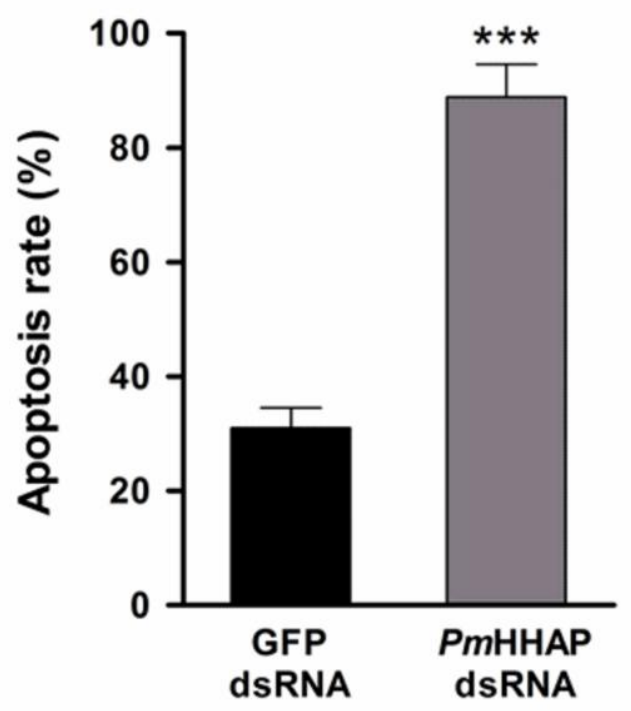


Figure 3

Figure 3.

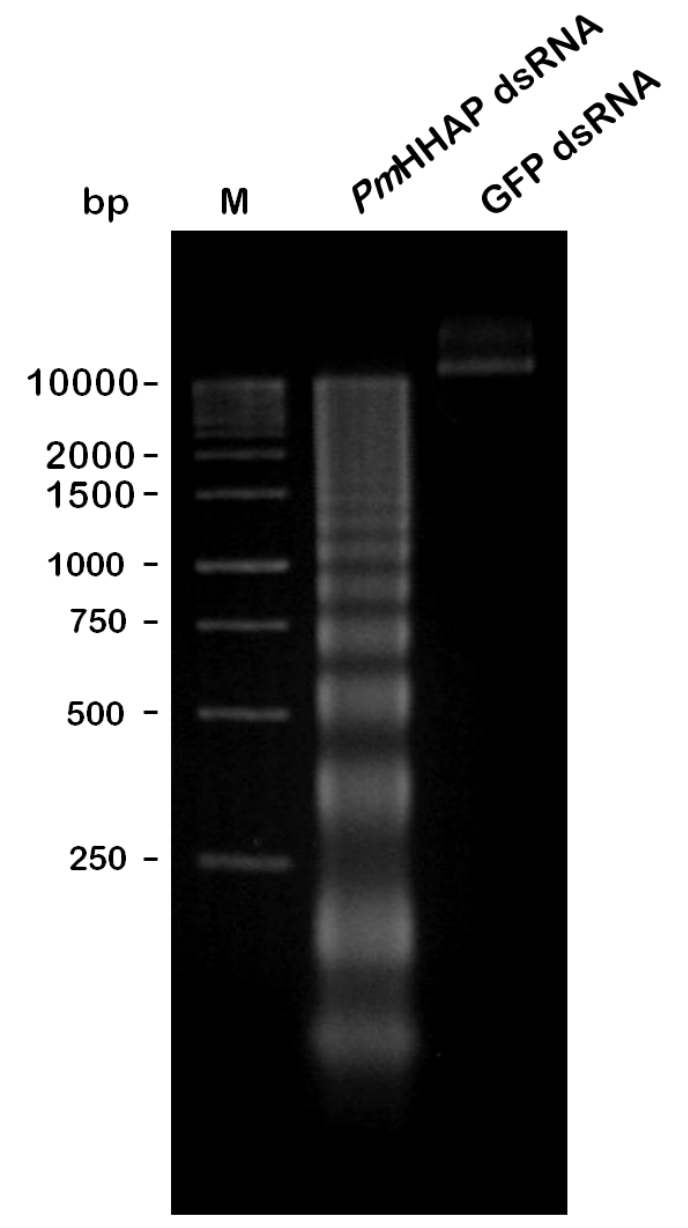


Figure 4

Figure 4.

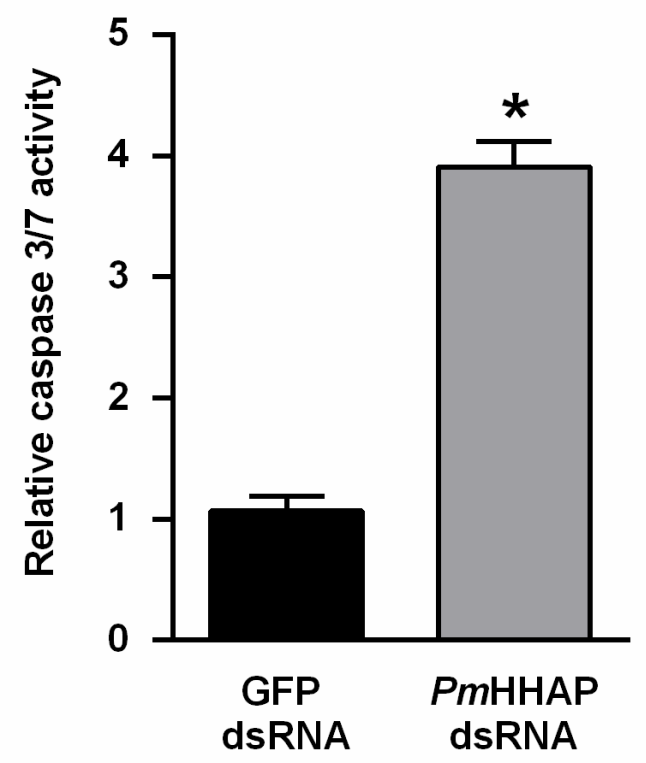


Figure 5.

(A)

PmCasp

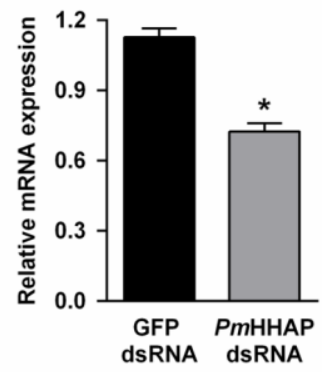

Cathepsin D

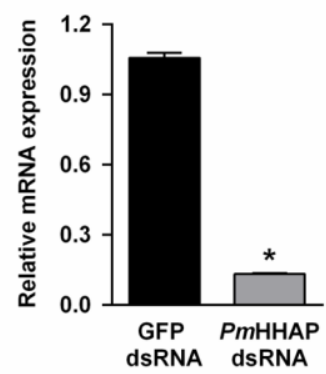

PmCaspase

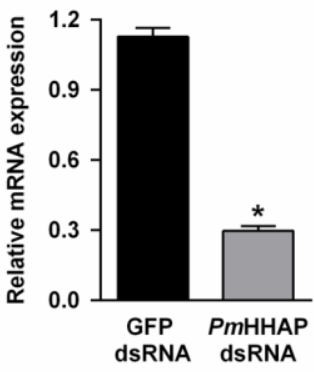

DAD1

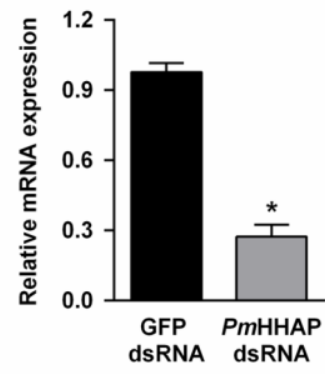

Cathepsin B

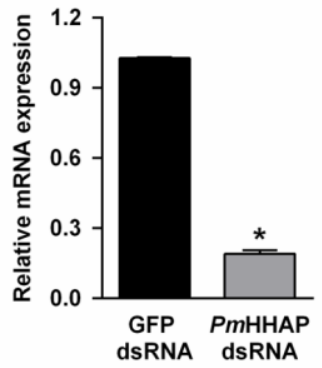

Survivin

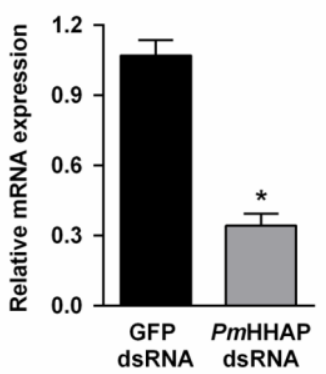

(B)

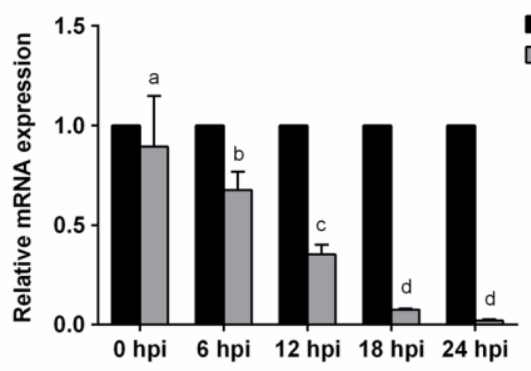

PmCasp

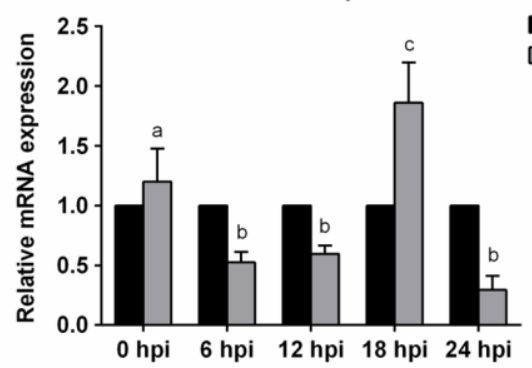

PmCaspase

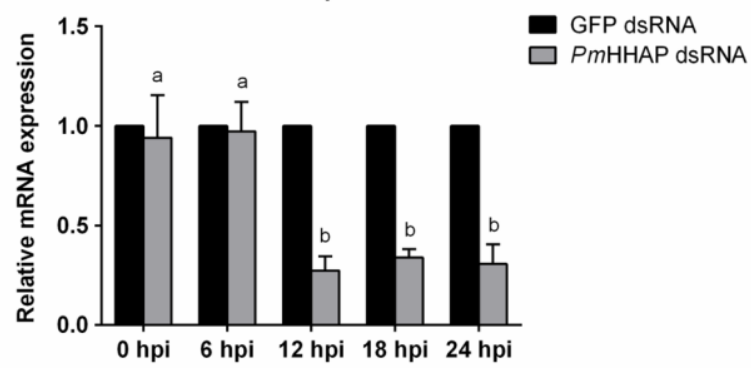


Figure 6

Figure 6.

(A)

$\begin{aligned} \text { PmHHAP/BD } & + \text { PmCasp/AD } \\ & + \text { PmCasp p } 20 / A D \\ & +P m \text { Casp p } 10 / A D \\ & + \text { Empty AD }\end{aligned}$

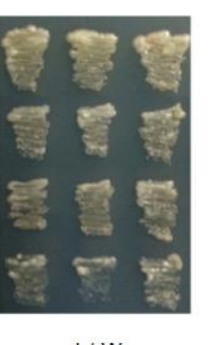

-L/-W

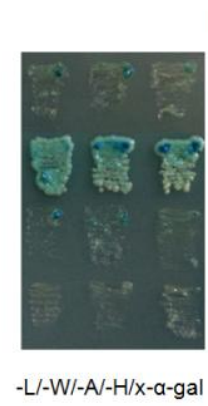

(B)

Interaction

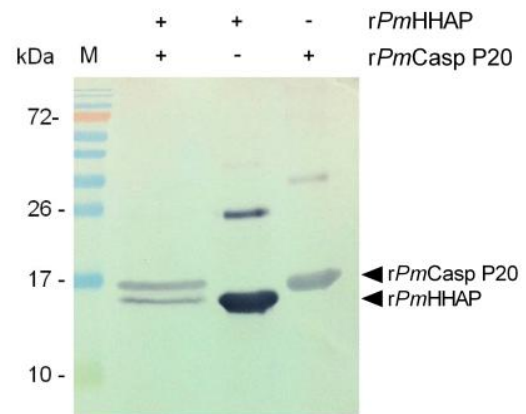


Figure 7

Figure 7.

(A)

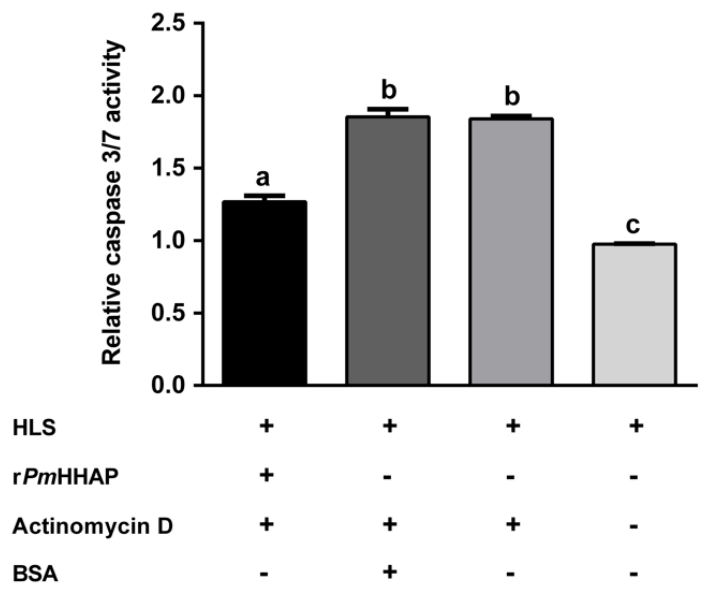

(B)

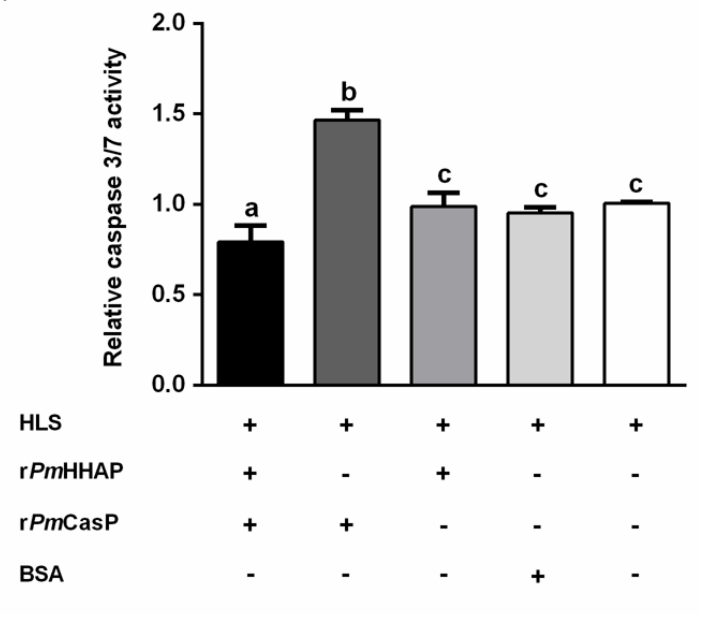

